\title{
ПоЛИТоЛОГИя
}

DOI: $10.17805 /$ ggz.2020.4.4

\section{Либерализм с русофобской спецификой}

А. Н. Ильин

Омский государственный педагогический университет

В статье обосновывается, что неолиберальная идеология таит в себе русофобские взгляды. Доказывается космополитизм и антидемократизм либеральной идеологии, которая стоит на защите интересов трансначионального капитала. Продемонстрирован феномен «косвенной русофобии», который выражается в подрыве благосостоянии страны посредством либеральных реформ. Приводятся некоторые иллюстративные фразы о русском народе, сказанные наиболее влиятельными представителями либерализма. Показано, что, скрываясь за риторикой о правах человека, российские либераль склонны к защите прав лишь тех людей, которые принадлежат к их идеологическому сообществу.

Ключевые слова: либерализм; русофобия; космополитизм

\section{Liberalism with Russophobic Particularities}

\author{
A. N. Ilyin
}

Omsk State Pedagogical University

The article argues that the neoliberal ideology is fraught with Russophobic views. The author reveals the cosmopolitan and antidemocratic character of the liberal ideology, which stands for the protection of the interests of transnational capital. The phenomenon of "indirect Russophobia" is presented. It is expressed in undermining the country's welfare through liberal reforms. The article comprises some illustrative phrases about the Russian people, which were coined by the most influential representatives of liberalism. It is shown that, hiding behind the rhetoric about human rights, Russian liberals tend to protect the rights of only those people who belong to their ideological community.

Keywords: liberalism; Russophobia; cosmopolitanism

ВВЕДЕНИЕ.

КОСМОПОЛИТИЗМ ЛИБЕРАЛЬНОЙ ИДЕОЛОГИИ

Либералы прошлых времен выступали за свободу слова и печати, за незыблемость прав личности и другие гуманистические и демократические ценности. Но времена ушли, идеология изменилась, однако не перестала 
называться либерализмом; хотя некоторые исследователи специально, чтобы подчеркнуть ее отличие от либерализма прошлого, именуют ее неолиберализмом.

Сегодня либерализм представляет собой экономически и социально деструктивную идеологию (см.: Ильин, 2018acd). Современные либералы являются западниками, западничество которых порой выливается в откровенную русофобию. Связь российского либерализма и русофобии уже была нами описана (Ильин, 2018b). Здесь мы продолжим свой анализ.

Либерализм представляет собой рупор капиталистической глобализации, который с уничижением смотрит на Россию и с подобострастием - на Запад. Он преодолел этническую, национальную принадлежность и стал космополитичной идеологией «граждан мира», хотя правильней было бы сказать, что он превратился в совокупность идеологем граждан алчного транснационального капитала против мира. Такая характеристика, как «гражданин мира», для либералов - необоснованный комплимент. Гражданином мира был древнегреческий философ Диоген Синопский, но не эти деятели. Ведь они, отказавшись от рода и племени, стали по сути защитниками глобального бизнеса, который ради своих интересов противопоставляет себя миру национальных государств, народов и этносов.

Они отрицают мысль, что проблемы России отчасти связаны не только с нашими пороками, но и с внешним - западным - влиянием. Они искренне продолжают считать, что так называемый цивилизованный мир желает принести России процветание и демократию, но недальновидное правительство и/или порочный народ не хотят принимать дары Запада. В этом мнении они едины даже несмотря на то, что времена Б. Н. Ельцина показали другую истину: окружившие тогда президента американские экономические советники давали ему такие рекомендации, которые погубили отечественную экономику, социальную политику, уверенность людей в завтрашнем дне. Можно привести много примеров из истории как России, так и всего мира, которые противоречат либеральному тезису о стремлении США и Запада в целом облагородить человечество. Но наша задача сейчас заключается не в демонстрации мифологичности этого тезиса.

По сути либеральная часть современного руководства России - это вещь для себя (а не для общества) и для глобального бизнеса. Как пишет А. И. Фурсов,«...антироссийская истерия на Западе питается несколькими мотивами - геополитическим и цивилизационным, направленными против русской культуры и государственности, и классовым ${ }^{1}$, необуржуазным, чья мишень - государство и культура как таковые. Перед нами единство классового

\footnotetext{
${ }^{1}$ Исправлено. В источнике: «классовыми».
} 
и цивилизационного, неудивительно, что паразитическая необуржуазия РФ активно содействует классово близким “глобалам" всей своей финансовой и информационной мощью в стремлении подавить “локалов”, т. е. прежде всего Русских. Так русский вопрос приобретает классовое измерение, а вовсе не является лишь этнокультурным» (Фурсов, 2018: Электронный ресурс; полужирный шрифт источника. - $A$. И.).

Либеральная ориентация на Запад противоречит усилению России, ее возрождению и развитию российского общества во всех смыслах этого слова. Кроме того, «либерализация современной России превратилась в процесс слома ценностей цивилизационной идентичности России и в ней - исторической и национальной идентичности русской нации. А либерализм, круша все на своем пути, все формы идентичности, не адекватные западным, - в идейное оружие ничем неприкрытого цивилизационного разбоя. В этом смысле главная проблема современной исторической модернизации России, осуществляемой от имени и во имя либерализации России, - идентификационная» (Козин, 2006: 52).

Наиболее радикальные либералы считают, что у русского народа нет никакой идентичности, кроме западной, и вообще поиск идентичности уводит его от единственно правильного пути. По вестернизаторской версии, Россия ничего принципиально ценного создать не может, а все значимое и достойное уважения следует искать в мире, именующим себя цивилизованным. Видится только два варианта: переход России на рельсы «просвещенного» мира или впадение в традиционный для России авторитаризм. Причем предлагается заимствовать как политические и экономические институты (систему в целом), так и культуру, а свои историю надлежит презирать как историю рабства.

Во-первых, такая позиция представляется непростительным упрощением, абсолютной когнитивной простотой, даже примитивизмом. Никто так и не доказал, что российской истории свойственны более авторитарные тенденции, чем западной (хотя либералы продолжают это постулировать). Поэтому высказанный тезис базируется на утверждении, далеком от истины. Альтернативы западному пути есть, и если космополиты и вестернизаторы не желают их видеть, следует говорить не об отсутствии альтернатив, а о слепоте этих «аналитиков».

Во-вторых, выстраивание такой безальтернативности само по себе противоречит принципам демократии. Либералы себя именуют приверженцами демократических ценностей и при этом навязывает одно - вестернизаторскорыночное - решение. А если народ сам захочет выстроить некий «особый» путь? Они об этом не задумываются, считая, что в этом вопросе мнение народа не авторитетно. Как заметил еще И. Р. Шафаревич, советские вестернизаторы (Г. С. Померанц, Б. И. Шрагин, А. Л. Янов и т. д.) представляли западно- 
центрично мыслящую интеллигенцию как элитарное сообщество достойных и образованных, а народ - как слепую, невменяемую, глупую, безответственную и раболепную массу, агрессивно настроенную по отношению к свободе и высшим ценностям культуры (Шафаревич, 2005).

Сегодня ситуация не слишком изменилась. Так, когда А. Б. Чубайс раскритиковал российский народ за отсутствие благодарности к олигархам, которые якобы выстроили страну (Наумкина, 2018:Электронный ресурс), он этими словами признал, что народ не поддерживает возникший в ходе либеральных реформ олигархат. Недаром говорят, что интеллигенция в долгу перед народом. Это действительно так. Следует вспомнить А. Грамши, который писал, что интеллигенция не должна превращаться в оторванную от народа касту или жречество, ей надлежит быть связанной с народом, понимать его (Грамши, 1959, 1991). Поддержка либеральных лидеров в России невысока. В этом состоит величайшая несправедливость современности: либеральная политика непопулярна, однако социально-экономический блок правительства продолжает ее реализовывать, а во властных эшелонах доля либералов намного выше, чем в народе. Политическое влияние отдельных групп несоразмерно их действительной общественной поддержке, проводимая правительством под давлением этих групп политика не соответствует воле большинства. Лишь американские пропагандисты и верная им российская часть либеральной оппозиции могут безответственно вещать, будто рыночникам симпатизирует практически все общество.

Но если давать бразды правления «хорошей» интеллигенции (естественно, не всякой, а либерально-западнической) и отбирать их у «плохого» народа, тогда от приверженности демократии не остается и следа. Здесь мы видим прямую аналогию с американской мессианской риторикой (которую наши либералы воздерживаются критиковать, но обрушиваются лишь на российский мессианизм). Американские лидеры постоянно твердят о необходимости навязывать свободу и демократию разным странам мира, даже если их культура совершенно не приемлет западных ценностей. В данном месте нас интересует вовсе не то, что США вместо этих ценностей несут разруху и бедность. Даже если бы эта страна действительно эффективно насаждала свободу и демократию, возникала бы обоснованная претензия в том, что мировой гегемон действует антидемократично - пренебрегает мнением самих народов, их культурой, которая может к западному взгляду на демократию относиться весьма прохладно или откровенно враждебно.

Здесь мы выходим на важное постулирование проблемы отличия либеральных элит от народа. Их мировоззрение, мышление, система ценностей не отражают народных. Однако они захватили практически всю внутреннюю политику России, что свидетельствует о недемократизме происходящего. Как 
заметил М. Г. Делягин, когда способ мышления и мировоззрения элит существенно отличен от наиболее распространенных в обществе, элита отрывается от социума, тем самым утрачивает свою эффективность и общественно полезные функции, которые делают ее элитой и оправдывают ее существование. Даже в одни и те же события народ и элита вкладывают разный смысл и высказывают порой прямо противоположные выводы (Делягин, 2016ab). Такая элита не просто думает иначе, чем народ. Она зачастую не воспринимает, не понимает, не хочет понимать и воспринимать мнение народа. Исходящие «снизу» ценности, идеалы, устремления, мнения и политические проекты игнорируются, поскольку отличаются от парадигмальных для элит. Такое антидемократическое стечение обстоятельств, называемое либерализмом, Россия переживает все время своего постсоветского периода. Оно является значимым вбивающим клин между обществом и элитами конфликтогенным фактором. Например, А. Р. Кох после теракта 11 сентября заявил, что ему все улочки родные в Нью-Йорке, а применительно к терактам в России 1999 г. сказал, что для него не было эффекта присутствия (причем в 1999 г. он находится в России, а в 2001 г. в США не был) (Делягин, 2016b). «Нет эффекта присутствия» по отношению к народу России, отрицание его как своего - это, пожалуй, характерная черта либерализма.

В-третьих, переход России на путь Запада уже себя проявил в ельцинский период, и народ столкнулся с бедностью, нищетой, экономической и политической десуверенизацией страны. Именно к возвращению в «благие» годы Ельцина призывают вестернизаторы. Это возвращение чревато новым культурным, экономическим и политическим кризисом. Либерализм для России катастрофичен, учитывая ее обширные пространства, «нерентабельные» климатические условия, культурный фактор и внешнее окружение.

В-четвертых, нецелесообразно ожидать, что западный мир воспримет Россию как равную и примет ее в свой общий дом. Тогда он ее не принял, навязывал свои решения, оказывал давление, заставлял отказаться от суверенности и неукоснительно поддерживать его во всех начинаниях (даже противоречащих национальном интересам России), и далее будет делать то же самое. Тем более своими словами и действиями русофобствующие политические элиты США и Европы продолжают доказывать снова истину о том, что Россию они не принимают и не собираются принимать как равную. К тому же нередко американские и европейские политические круги требуют от Кремля политических и экономических действий, которые они сами не предпринимают; уже это говорит о том, что они не желают видеть в России некий аналог, копию их систем. Поэтому призывы (которые высказывают А. Л. Кудрин и другие либералы) принять условия Запада, после чего последний отменит антироссийские санкции - это предложения капитулировать в одностороннем 
порядке, сдать свои позиции, взамен получив полную десуверенизацию и абсолютное обеднение народа.

По сути либераль-вестернизаторы предлагают построить в России не западную демократию, а такой режим, который будет выгоден «цивилизованному» миру, издавна противопоставившему себя России и с вожделением глядящему на природные ресурсы нашей страны. Скорее, не российский народ, со всеми его пороками, является забывшим о свободе и чувстве собственного достоинства. Либеральный «народ» выступает лакеем перед западными покровителями.

Противопоставляя себя народу как антинарод, прослойка либералов-западников выбрасывает себя из подлинной духовно-культурной реальности социума в подобие чистых лабораторных условий. Она мнит себя более просвещенной, умной, образованной. Она считает народом именно себя. Ее высокомерию и тщеславию нет предела, и за счет принижения народа она себя возвеличивает, низвергая действительно духовные авторитеты и на их месте воздвигая культурную низость - настолько же пошлую, как прислужничество перед Западом и русофобская риторика. Либеральной прослойке претят национальная история, вписанный в нее героизм, корни духовной жизни, моральные нормы общества и его культурные ценности. Ей глубоко противен взгляд на что-либо с национальной позиции, а Россия воспринимается как страна, обладающая внеисторическим бытием, выброшенная из процесса нормального исторического становления. Сам же народ эта прослойка воспринимает как угрозу для своего сообщества, всячески создавая подлинно классовую ситуацию, в которой она как представитель власти реализует свою гегемонию (гегемонию меньшинства) в собственных интересах и в ущерб интересам народа. Последний не вызывает у западников никакого сострадания, он просто выброшен из поля их моральной ответственности. Разнузданный либерализм 1990-х гг. это показал на практике. Неудивительно, что деструктивность своих реформ либералы стали списывать на народ. Они утверждали, будто он такой архаичный и укорененный в каком-то традиционализме, что его не получилось трансформировать в «нормальный» - индивидуалистичный, буржуазный, ценящий дух конкуренции, уважающий частную собственность (уважение к которой сами же реформаторы подорвали осуществленным грабежом) и т. п. Не только социальная деструктивность реформ, но и перекладывание ответственности в стиле «какой-то неправильный у нас народ, а с нами все в порядке» отлично показали русофобский и антидемократичный лик либерализма.

Россия стоит перед рисками того, что мы называем «негативным заимствованием» западных ценностей — от философии ювенальной юстиции до безнравственных веяний в искусстве. Публично испражняющиеся художники, прибивающие свои гениталии к брусчатке, стали проявлением нового стиля, 
креатива и смелости. Духовное бесплодие, извращенная фантазия, антиморальные и антиэстетические выверты выдаются за новаторство, прогрессивное искусство, новые формы эстетики. Многие из таких деятелей составляют либерально ориентированную прослойку общества, проникнутую радикальным западничеством, эгоистическими, индивидуалистическими и потребительскими ценностями. Она называет себя креативным классом. Ряд этих носителей и распространителей антипатриотизма и даже русофобии представляют собой продажную группу людей, для которых характерна идеология социалдарвинизма и высокомерие по отношению к народу.

Настоящий креативный класс составляют не олигархи, пиарщики, финансисты, местные выразители интересов транснационального капитала, брокеры, политтехнологи, торговые посредники, офисный планктон и деятели шоу-бизнеса. Настоящий креативный класс - учителя, врачи, вузовские преподаватели, ученые, инженеры - те, кто, загнан в социальное небытие, кто еще в 1990-е гг. потерял поддержку власти и кому с помощью либеральных СМИ придан облик неудачников. Именно они - настоящие прогрессисты. Все же эти возомнившие себя креативщиками представители зомбирующего сознание людей сектора симулякров - регрессоры, чья деятельность не просто общественно бесполезна, а социально вредна. Однако в мире рыночной экономики, тотальной коммерциализацией все ставящей с ног на голову, эти представители социально безответственного труда становятся намного более уважаемыми и успешными, чем те креативные работники, без труда которых общество не сможет развиваться и даже существовать. Справедливое общество - то, где настоящий креативный класс, в отличие от фиктивного, пользуется социальным уважением и получает достойный доход от своей действительно общественно полезной работы. Так называемый креативный класс не соответствует своей деятельностью и потребностями ни рабочему классу (поскольку не желает заниматься социально необходимым трудом, а вместо этого создает симулякры), ни классу реальных новаторов (поскольку действительно креативного в нем мало).

Выставляя себя креативным классом, либералы как бы подразумевают, что настоящему креативному классу не стоит ждать от них поддержки, если все-таки они станут во главе страны. А он и не ждет. Сторонники цветной революции в норковых шубах, эти адепты влезшего на политическую сцену потребительства только отвратили от себя массу народа своим показным гламуром и социально высокомерной риторикой о креативном классе. Тем же, кто остался им верен, трудно понять, что их вожди не принадлежат их среде. В глубине души либералы-западники осознают свою непопулярность в народе, но не находят смелости в этом признаться. Возможно, эта непопуляр- 
ность еще больше подстегивает в них неприязнь к российскому народу, который давно перестал быть для них своим.

Но применим ли к России либеральный западоцентризм и нужен ли он вообще нам? Н. Я. Данилевский в свое время заметил, что Россия не питалась соками европейского древнего мира, не составляла части западных империй, не связывалась с Западом феодально-аристократической сетью, не знала соответствующей формы религии, схоластики и западных идеалов искусства. Россия не принадлежит к Европе, а та не желает ее принимать, и, вооружаясь русофобией, воспринимает российскость как нечто чуждое и враждебное. Она считает нормой вероломно вмешиваться в дела России, но категорически не приемлет российское влияние на ее дела (Данилевский, 1991). Конечно, Данилевский является глубоко реакционным автором, который считает бедами России многие действительно прогрессивные заимствования с Запада. Но по части постулирования русофобских тенденций Европы он прав.

Современные российские либералы отводят взгляд от вероломного вмешательства США и их европейских сателлитов в дела России и множества других стран мира, но активно отстаивают нежелательность российского влияния на дела кого бы то ни было. Американские элиты поддерживали таких рьяных борцов с демократией, человеческой жизнью, суверенной экономикой, правами человека, как Пиночет, Мобуту, Сухарто, представители семейства Сомоса. Истеблишмент США прославился нарушающими международное права бомбежками различных стран, инициированием цветных революций, буквально вынуждением национальных правительств открывать свои рынки для транснационального капитала, результат чего - рост бедности и ликвидация суверенитета. Но российские либералы не торопятся критиковать звездно-полосатый флаг. Получается, американцы имеют право влиять на кого угодно в своих интересах. Для России либерализм - идеология закабаления.

\section{КОСВЕННАЯ РУСОФОБИЯ ЛИБЕРАЛИЗМА}

Либерализм совсем необязательно предполагает откровенную русофобию. Имманентная ему русофобия менее явна, она обычно скрывается за пафосными высказываниями типа «мы не русофобы, мы просто хотим сделать Россию лучше». Именно здесь приходит на ум фраза о том, что в мирное время, в отличие от военного, враги рядятся в нашу форму. Либералы уже сделали Россию «лучше» в 1990-е гг., разграбив ее и позволив вывезти многие ее активы за рубеж. Отрицание самого наличия конкурента и оппонента (американских элит и наднационального бизнеса), желающего присвоить ресурсы страны и уничтожить ее государственный суверенитет, можно приравнивать к деструктивной пропаганде. Либералы раньше убеждали (и продолжают это делать) в отсутствии внешних конкурентов на международной политической и 
экономической арене, хотя говорят о конкуренции на внутристрановом поле. Нет ли здесь противоречия? Они любят вещать о конкуренции между различными экономическими и политическими акторами внутри отдельно взятой страны, но обходят разговоры о конкуренции между странами. Складывается впечатление, будто таковой вообще не существует. Либералы нередко называют архаичными и ушедшими в историю все призывы к социализму, социальной справедливости, протекционизму и защите национальных производителей (и целых стран) от внешних конкурентов, несмотря на простой факт: конкуренция между странами никуда не исчезла, равно как дипломатическое, экономическое и геополитическое давление на Россию. Более того, им претит воспитание народа в духе патриотизма, как и применение всерьез термина «национальные интересы».

Либерализм не то чтобы в прямом смысле русофобен - ведь среди носителей этой идеологии есть разные люди, мировоззрение которых отличается определенной степенью вариативности. Однако ему имманентно присуща социальная, экономическая, культурная и политическая деструктивность, которую при разговоре о России можно связывать с формой косвенной русофобии.

Недаром Л. А. Зеленов, М. Г. Большаков и А. А. Владимиров расширяют понятие «русофобия», включая в список русофобов не только руссоненавистников в традиционном смысле этого слова, но и сторонников капитализма. Их аргументация носит вполне марксистский характер: поскольку именно народ создает своим трудом богатство, а горстка частно-собственников его присваивает и заодно унижает и угнетает трудовой народ, чем расписывается в ненависти к народу (Зеленов, Большаков, Владимиров, 2018). Точка зрения, которая опирается на классический тезис о противоречии между общественной формой производства и частной формой присвоения, имеет особенное право на существование, особенно когда мы смотрим на катастрофизм неолиберальных реформ.

Можно полагать, будто советское руководство следовало к достижению общественно полезных целей, используя далеко не всегда гуманные методы. Т. е., не считаясь с многочисленными жертвами, оно стремилось обустроить Советский Союз в военном, экономическом, промышленном, социальном, культурном и др. смыслах. И ему это удалось. Но либералы следовали к общественно вредным целям, пользуясь негуманными методами. Они, также не считаясь с жертвами, стремились разрушить Россию. Недаром катастрофизм последствий их реформ сравнивают с гитлеровским нашествием - в том числе по показателям демографического упадка. И во многом эти стремления им удалось воплотить в реальность. Поэтому в плане социальной пользы и ответственности советский режим выигрывает. Возможно, именно поэтому либералы так его ненавидят. 
С точки зрения либерализма, государство должно уйти от экономического регулирования, отказаться от социальной политики, перестать оказывать помощь широким слоям общества. Развитость медицины и образования усматриваются в их платном характере. Государство должно обеспечить полную приватизацию, открыть рынок для транснациональных корпораций, отменить пошлины и тарифы, отказаться от субсидирования отечественных производителей. При этом элиты западных стран сами не торопятся углублять эти процессы у себя, но активно убеждают, что Россия должна их реализовывать в полном объеме.

Либерализм отменяет множество социально необходимых функций, которые обязано реализовывать государство. С точки зрения этой идеологии, оно должно уйти от защиты прав трудящихся, борьбы с бедностью, безработицей и социальной поляризацией, обеспечения социальной безопасности, совершенствования инфраструктуры, стратегического планирования, обеспечения долгосрочного развития, поддержки фундаментальной науки, регулирования основных средств производства, обеспечения людей доступными и качественными образованием и медициной, ограничения экономически вредной деятельности финансовых спекулянтов, поддержки обороны страны, конструирования высокоморального контента в СМИ, обеспечения суверенитета страны.

Минимизация роли государства плюс его подчинение глобальному бизнесу (что проповедует неолиберализм как необходимость) лишают государство возможности выполнять общественные функции и делают его просто бесполезным для общества. Либеральное государство и государство всеобщего благосостояния (социальное государство), если брать каждое из них в максимально чистом виде, выступают по отношению друг к другу антагонистами.

Когда повышен «градус приватизации», беднеет бюджет, ряд предприятий перестает технологически эффективно функционировать (частник снижает издержки на оборудование, в том числе необходимое для минимизации рисков, и на зарплаты), а некоторые переходят в руки иностранцев (мы это проходили в 1990-е гг.). Государственная политика — несмотря на мнение либералов - является не проблемой, а инструментом решения проблем. Проблемой она становится тогда, когда ее нет, точнее, когда она становится по-либеральному сжатой, нерешительной, отказывающейся следовать интересам общества.

Говоря о свободе и демократии, либералы своими действиями приводят к аннигиляции демократичности. Ведь, отодвигая в сторону государство, лишая его права реализовывать свои функции, они отдают общество в управление глобального бизнеса, который в условиях открытой экономики и приватизационного бума осуществляет массовую скупку активов. Если 
представителей государственной власти все-таки выбирают, и они имеют обязанности перед обществом, то деятелей корпоративной власти никакие народы не избирают, их деятельность совершенно неподотчетна.

Интересы транснационального бизнеса находятся в противоречии с интересами общества. Глобальному бизнесу необходимо только урезанные, слабые в силу своей отстраненности от экономики либеральные государства, которые, а также подчиняющиеся им полицию и армию, можно использовать в бизнес-целях, защищать интересы корпораций от интересов народа страны. Лоббирование неолиберализмом рыночных принципов и так называемой свободной торговли, экспорт монетаристской идеологии в мир взламывает национальные суверенитеты, десубъективизирует нации, усиливает международное неравенство, эксплуатацию, максимизацию глобальным бизнесом прибылей путем обеднения народов.

Бизнес пропагандирует потребительскую идею, согласно которой выпускаемый им товар завтра устареет в модном смысле, и потому потребителю нужно будет покупать более «современный» аналог. Также бизнес нередко специально производит недолговечную (не в модном, а в физическом смысле) продукцию, чтобы она быстро приходила в дисфункциональное состояние, и потребитель вновь шел за покупкой. Все эти бизнес-ухищрения, освобожденные от государственного вмешательства в экономику, ломают как экологическое сознание взращенных на консюмеристских ценностях масс, так и оказывают катастрофически излишнее давление на экосреду, увеличивая количество мусора.

Неудивительно, что в школах и вузах распространяется коммерческая реклама, проходят массовые акции в поддержку товаров спонсора, фирмы могут влиять даже на содержание учебных программ. Поэтому следует констатировать, что отход государства от экономической сферы является автоматически отходом от культурной сферы. Излишняя рыночность, избыточная коммерциализация и монетизация ломают общество, его нравственные устои, а вместе с тем и моральное сознание людей.

Либерализм правильно было бы называть рупором глобализма, монетаризма, оправдания растущего социально-экономического неравенства, индивидуалистических и крайне эгоистических ценностей и безудержного потребительства. Неудивительно, что после развала СССР и утверждения новой, пореформенной, либеральной России США и глобальные корпорации получили от нашей страны баснословное количество финансов, новые технологии, массу высококвалифицированных специалистов и тонны ценных материалов. Именно либерализм был воплощен в реальность в 90-е гг. в России, и все мы знаем, к каким катастрофическим последствиям для общества, экономики, культуры и государственного суверенитета это привело. 
Для подробного осмысления результатов насаждения в России антинародного либерального проекта потребовалось бы написать полновесную книгу. Здесь мы лишь тезисно изложим основные положения.

1990-е гг. ознаменовались ростом смертности и падением рождаемости, сокращением средней продолжительности жизни, тотальным расслоением общества по доходам. В результате реформ сформировались и надолго укоренились такие нехарактерные для СССР явления, как безработица, бездомность, наркомания, работающая бедность.

Катастрофически упали: численность рабочих, занятых в промышленности, сельском хозяйстве и науке; выпуск квалифицированных рабочих в системе начального профессионального обучения; поголовье крупного рогатого скота; тираж изданных книг и брошюр; инвестиции в основной капитал России; вложения в строительство, транспорт и связь, торговлю, сельское хозяйство.

Стали массово закрываться заводы и промышленные предприятия. Различные виды производства, в том числе системообразующие отрасли, столкнулись с серьезным кризисом. За годы реформ никаких серьезных прорывов в технологиях сделано не было; вместо этого практически вся производственная сфера вверглась в деградацию. Многие предприятия после безответственной приватизации подверглись разворовыванию. Активы вывозились за рубеж. Основным производственным фондам и мощностям было отказано в ремонте и восстановлении, они вовлеклись в процесс старения и разрушения, что вместе с падением квалификации и ответственности управленцев и работников послужило одной из причин роста технических аварий и катастроф. Также и жилищно-коммунальное хозяйство столкнулось с нехваткой средств на поддержку и развитие. Произошли возвышение спекулятивного сектора, колоссальное системное экономическое падение и рост государственного долга.

Экономику рыночные реформаторы открыли для деятельности транснационального бизнеса, которого совсем не заботят проблемы и нужды российского общества. Напротив, в отечественном производстве он видит конкурента и стремится его уничтожить. Во многом ему это удалось. Важное «достижение» либерализма - переход России к спонсированию своего геополитического конкурента: вкладывание финансовых средств в гособлигации США, взятие кабальных кредитов у международных организаций и обязательство Центрального банка РФ для эмиссии рублей закупать американские доллары.

Реформы вытеснили государство из сфер, в которых только оно может принимать решения, и лишили его возможности реализовывать социальные функции, доступные только ему. Социальная политика свернулась, народ погряз в бедности. Взлетело ввысь имущественное расслоение, на фоне тоталь- 
ного обеднения социального большинства сформировалась горстка крайне влиятельных олигархов.

Либерализация выбросила большинство людей из нормальной жизни. Конституционные положения о праве человека на жизнь и достойное существование были нарушены. Началась программа перевода медицины и образования на платные рельсы (и снижения их качества), что стало важным аспектом сворачивания социального государства. Вследствие массового ухудшения материального положения наметился рост самоубийств, а также заболеваемости, в том числе венерическими болезнями (что характерно, когда в СМИ рекламировались сексуальная вседозволенность и проституция). Ухудшилось физическое и психическое здоровье общества. Актуализировались социальные страхи - потерять работу, не получить медицинскую помощь, не обеспечить детей образованием и т. д.

СМИ освободились от нравственных норм и принялись тиражировать потребительство, вещизм, эгоизм, индивидуализм, вседозволенность, социалдарвинизм, что сильно надломило культуру народа. Разрослась преступность, в том числе детская; это было следствием катастрофического падения финансового и социального положения большинства, крушения надежд, надлома культуры, коррумпированности и бесполезности правоохранительных органов. Произошел спад боеготовности армии и ее морального духа.

Количество и качество внезапно обрушившихся на людей проблем вместе с широко функционирующей программой манипуляции обществом вызвали тяжелую дерационализацию сознания. Это была благодатная почва для возникновения большого числа сект и околосектантских организаций со всеми вытекающими отсюда социальными и экономическими последствиями. Вместе с падением квалификации работников начало расти невежество в различных социальных группах, в том числе во власти, вплоть до распространения откровенного мистицизма.

Россия утратила политический, экономический и культурный суверенитет. «Вершители глобализации» оказывали успешное влияние на политику местной элиты, выбивали у нее выгодные для себя (и невыгодные для российского народа) экономические решения, а также повсеместно в СМИ насаждалась новая культурная гегемония, обогащенная американизмом. Про себя как субъекта геополитических действий Россия забыла, став объектом чужих геополитических решений. Выражаясь языком мир-системного анализа, она была выброшена на мировую периферию.

Власть только создавала угрозы, она сама стала угрозой для страны и ее общества, и при этом - как еще один результат реформ - была отключена эффективно действующая в советское время система распознавания и предотвращения угроз. Если бы она сохранилась, едва ли были бы приняты 
непродуманные, буквально предательские решения, которые бросили страну в нишу третьего мира.

В общем, либеральные реформы привели к мегакризису, который можно разделить на экономический, демографический, социальный, политический, геополитический и культурный кризисы. Были загнаны в глубокое подполье, лишены развития наука, культура, спорт, экономика, социальная сфера, воспроизводство населения, вооруженные силы и т. д. Реализовывались эти кризисы российскими элитами под диктовку и с «помощью» американских чиновников и структур типа Всемирного банка и Международного валютного фонда. Экономические потери от либеральных реформ 90-х гг. соотносимы с потерями СССР во время войны с нацистской Германией. Сами же либеральные реформы похожи на гитлеровский план «Ост», предполагающий снижение питания, деградацию медицины и образования, наконец, вымирание. Власть не особо заботилась падением уровня жизни людей, демографическим кризисом (рост смертности и спад рождаемости), нападками на национальную культуру и обескультуриванием широких масс людей, притеснением русских в других государствах. Она вообще не считала русскую культуру и русскую идентичность чем-то важным, значимым и в принципе существующим.

Невозможно бороться с бедностью и имущественным расслоением типичным либеральным рецептом - сокращением финансирования социальных программ. Оно приводит к еще более расширяющемуся ареалу бедности и усилению социально-экономической поляризации. Вовсе не ослабление государства, а госрегулирование способно обеспечить людей такими правами и свободами, как право на жизнь, достойную работу, качественные и эффективные здравоохранение и образование, свобода от лишений и страха за будущее. Либерализм же дисфункционализирует эти права, наделяя бизнес (в том числе глобальный) правами эксплуатировать трудящихся и осуществлять манипулятивные рекламные кампании.

Превратив некогда сильную страну в пепелище, либеральная когорта еще и гордится этим, похоже, воспринимая за честь борьбу с собственным народом, а за совесть - деструктивную деятельность поистине масштабного размаха. В конечном счете деструкция - это тоже творчество, но с обратным знаком. Нельзя сказать, что всем либералам свойственны откровенно русофобские настроения, но, во-первых, их реформационные действия носят антироссийский характер, и, во-вторых, либерализм как идеология, поддерживающая проект глобализма, вполне солидарна с русофобскими интенциями. В действиях либералов мы видим реализацию русофобского проекта. Здесь русофобия выражается не в риторике, а в экономических и политических решениях. Но и риторика этой социальной прослойки тоже таит в себе много русофобских мифов. 


\section{ПРЯМАЯ РУСОФОБИЯ ЛИБЕРАЛОВ}

Когда российские либералы, лакействуя перед заокеанским хозяином, перенимают его нарратив, их некогда неявная либеральная русофобия становится вполне очевидной. Приведем несколько высказываний либеральных авторов (если не указано иное, цит. по: Цитаты ... , 2011: Электронный ресурс; Сбруев, 2013: Электронный ресурс).

- «Русская нация - раковая опухоль человечества... Русских нельзя с правами пускать в европейскую цивилизацию, их положили у параши, и правильно сделали» (Валерия Новодворская).

А ведь либерал-реформаторы уверяли, что Россию примут на равных в общеевропейский дом. Очевидно, что обманывали, а Новодворская в этих словах выразила не свое личное отношение, а идеологическое ядро именно западно-либерального восприятия русских.

- «Всем на свете стало бы легче, если бы русская нация прекратилась» (Валерий Панюшкин).

Только автор этого высказывания не конкретизировал, что под словом «всем» он понимает исключительно тех, кто назвал себя самыми исключительными; вспомним хотя бы тезис Б. Обамы (и многих его исторических предшественников) об американцах как исключительной нации.

- «Страна не такова, чтобы ей соответствовать!.. Ее надо тащить за собой, дуру толстож...пую, косную! Вот сейчас, может, руководство пытается соответствовать, быть таким же бл...ским, как народ, тупым, как народ, таким же отсталым, как народ» (Татьяна Толстая).

Только где же критерии соответствия? Если предлагается соответствовать западному миру, тогда надо, подобно ему, создать по всей планете кучу колоний; подвязать другие страны на свою валюту; спонсировать в ряде обществ выгодные для себя цветные революции; с помощью своих ВБ и МВФ подсаживать целые народы на экономические ловушки; бомбить любые народы по собственному произволу (как это делают США в обход международного права); лишать другие страны их национального суверенитета. Но такая деятельность является одновременно подражанием Западу и вместе с тем крайней формой конкуренции ему, которую он просто не допустит.

- «Я перечитал всего Достоевского, и теперь к этому человеку не чувствую ничего, кроме физической ненависти. Когда я вижу в его книгах мысли, что русский народ — народ особый, богоизбранный, мне хочется порвать его на куски» (Анатолий Чубайс).

Автор этих слов, судя по результатам его деятельности, вместо созидания преуспел в искусстве рвать на куски - экономику, энергетику, уровень жизни народа. Конечно, русский народ, как и всякий, не является исключительным, однако Чубайс негодует в отношении Достоевского, но умеряет свое 
возмущение, когда элиты других известных нам народов в открытую называют себя исключительными. Видимо, только русским нельзя ни на что претендовать.

- «Представьте, организовали в стране по-настоящему полностью демократические выборы, основанные на волеизъявлении трудящихся с равным доступом к СМИ, к деньгам... Результат таких выборов оказался бы на порядок хуже, а возможно, просто катастрофичен для страны» (Анатолий Чубайс).

А за что же, как не за демократию в самом широком смысле, на словах выступали реформаторы типа Чубайса?

- «Большая часть российского населения ни к чему не способна, перевоспитывать ее бессмысленно, она ничего не умеет и работать не хочет. Российское население неэффективно. Надо дать ему возможность спокойно спиться или вымереть от старости, пичкая соответствующими зрелищами» (Дмитрий Быков; Быков, 2012: Электронный ресурс).

Вот уж действительно социал-дарвинизм, граничащий с откровенным фашизмом. И ничего не говорится о критерии неэффективности российского населения. Неужели оно более неэффективно, чем населения других стран? Как это сопоставить, оценить, сравнить? В принципе большинству либералов свойственно противопоставлять себя собственному народу, бедных воспринимать как недостойных права на жизнь, а богатых уважать только за их обеспеченность, которая выступает показателем человечности. Некоторые даже высказывают мысли о голубой крови и о том, будто бедность генетически запрограммирована. Только эта идеологема, оправдывающая грабительский и понижающий уровень жизни неолиберализм, абсолютна антинаучна. Ее можно поставить в один ряд с убеждениями в существование рептилоидов-анунаков, с верой в круглость Земли и телегонию и т. д. Только в отличие от нее данные идеи не являются столь разрушительными. Фраза о запрограммированной бедности находит много общего с типично фашистскими идеями. И если мы предположим, что не отдельным либеральным активистам, а в целом этому сообществу (пусть при наличии некоторых исключений) свойственны презрение и враждебность к бедным, возникнет резонный вопрос: как данная идеологическая позиция соответствует их обещаниям поднять уровень жизни народа? Русофоб не будет заботиться о национальных интересах русских. Аналогичным образом ненавистник не бедности, а бедных людей, воздержится от помощи им выйти из незавидного социально-экономического положения.

- «...меня спрашивают, что я могу сказать по поводу того, что 70 \% российского народа одобряет запрет на усыновление детей американцами. И я скажу очень коротко. Это доказывает, что чернь во все времена остается чернью» (Юлия Латынина; цит. по: Юлия Латынина ... , 2013: Электронный ресурс). 
Похоже, показатель черни - это неодобрение усыновления детей американцами, которые, наверное, являются настолько уважаемыми (исключительными), что только чернь им может в чем-либо отказать.

- «Русских надо убивать, и только убивать - среди них нет тех нормальных, умных, интеллигентных, с которыми можно было бы говорить и на понимание которых можно было бы надеяться» (Борис Стомахин).

Подобное высказывание - достойный предмет рассмотрения психиатров.

- «Такие вот люди называются быдлом - которые завидуют и ненавидят меня... И эта черта, кстати, свойственна именно русским...» (Ксения Собчак; цит. по: Люблю евреев ..., 2008: Электронный ресурс).

Во-первых, непонятно, почему именно завидуют. Не проекция ли это, выражаясь языком психоанализа? Во-вторых, говорить про неприятие вместо ненависти вполне осмысленно, учитывая деятельность этой гламурной дивы, которая своим «Домом 2» внесла свой вклад в дело аморализации молодежи. И такое неприятие вполне оправданно с точки зрения нормальных моральных норм, а не тех норм, которые выработали для себя Собчак и другие либералы.

- «Российские люди во многом похожи на крупный рогатый скот. Они стерпят все, что угодно» (Евгения Чирикова; цит. по: Чирикова ..., 2011: Электронный ресурс).

Неужели рогато-скотского терпения не наблюдается у других народов? Конечно, нет, ведь, с точки зрения либералов, презумпция виновности бремя именно русских, и только их.

- «Пора прекратить лицемерные причитания о чувствах ветеранов, которых оскорбляют нападки на советскую власть. Зло должно быть наказуемо. Презрение потомков - самое малое из того, что заслужили строители и защитники советского режима» (Александр Подрабинек; цит. по: Подрабинек, 2009: Электронный ресурс).

Кто сказал, что советская власть - зло? Империей зла нас назвали те, кто совершают зло, но именуют себя добром. Похоже, мы должны презирать наших предков за то, что они своими силами создали великую страну с колоссальными социальными гарантиями и потенциалом противостоять мировому гегемону. Видимо, от нас требуют презрения к предкам за то, что они посмели себя противопоставлять тем, кто нарек себя глашатаями демократии, но на деле являются мировыми грабителями.

- «России мешают русские - основная масса наших соотечественников живёт в прошлом веке и развиваться не хочет... Русские еще очень архаичны. В российском менталитете общность выше чем личность... Большая часть (народа) находится в частичной деквалификации... Другая часть - общая деградация» (Игорь Юргенс). 
Похоже, предполагается, что только либеральная когорта, в отличие от простых русских людей, вела к развитию страны- да так вела, что ухудшение во всех сферах жизни страны назвала развитием. Именно с последствий их деятельности нужно списывать известный шутливый тезис «оптимизация путем ликвидации». И мало плохого видится в том, что общность выше личности. Конечно, следует учитывать интересы как общества в целом, так и личности, сохраняя баланс. Но либерализм выступает за абсолютный индивидуализм, не совместимый с развитием (и жизнеспособностью) общества. Поэтому явно не либералам следует говорить развитии.

- «У русского человека нет чувства эгоизма, а значит, чувства ответственности. А так как у русского человека нет чувства ответственности, то разговор с ним может быть только один: вдарил палкой ему по голове, и он присел» (Андрей Кончаловский; цит. по: Палкой по голове, 2006: Электронный pecypc).

Вообще-то эгоизм и ответственность - далеко не синонимы. А «метод палки» явно не соответствует либеральной демократической риторике, но он вполне соответствует либеральной практике, которая вместо демократии предполагает методологию «иного не дано».

- «Сначала 1917 год, потом сразу 1937-й. Два подряд уничтожения элиты привели к тому, что Россия стала страной генетического отребья. Я бы вообще запретила эту страну» (Ксения Собчак; цит. по: По лезвию ножа ... , 2015: Электронный ресурс).

Но почему-то Собчак не стремится запретить страну, которая больше всех в мире вмешивается в дела других стран, а результатом вмешательства является падение уровня жизни в странах-объектах и перетекание их ресурсов в лоно вмешивающегося субъекта. Собчак, стремившаяся в 2018 г. участвовать в президентской гонке, могла бы сделать данный тезис основой своей предвыборной кампании. Это выглядело бы по крайней мере честно. А когда большинство «генетического отребья» отказалось бы ее поддерживать, она, как обычно, заговорила бы о том, что ее жутко обидели, ей нахамили, выборы сфальсифицированы, и на самом деле ей симпатизирует социальное большинство. Используя термины типа «быдло» или «генетическое отребье», либералы вроде Собчак пытаются расчеловечить русский народ, но на самом деле они расчеловечивают самих себя; ведь соответствующая риторика позволяет сделать весьма определенный вывод об их моральном сознании.

- «Я, честно говоря, не вижу особой проблемы, и если Россия разделится по Уральскому хребту. Я думаю, что это неизбежно» (Евгения Альбац; цит. по: Особое мнение, 2013: Электронный ресурс).

К счастью, неизбежность оказалась фантазией. Стоит заметить, что либералы вслед за своими заокеанскими хозяевами нередко призывают к разделу 
России, к ненадобности «кормить Кавказ». Но они молчат, когда речь идет о свободном Техасе или независимой Ирландии.

- «На колени, твари, и просить прощения у нескольких поколений украинцев. Умолять о прощении! Пока граждане России не начнут настоящее покаяние, произнося проклятья в адрес Путина, исполнившего роль Гитлера, никто никого не должен прощать. За преступление нужно нести ответственность. Тот, кто его совершил, должен быть наказан»(цит. по: Боровой - россиянам ..., 2014: Электронный ресурс).

Эти слова принадлежат председателю партии «Западный выбор» Константину Боровому, который таким образом после присоединения Крыма предложил стратегию искупления вины русских перед украинцами. Только непонятно, в чем наша вина, почему мы твари, в чем состоит наше преступление и кто сказал, что Крым не является частью России. В данном высказывании мы видим очередной сепаратистский лозунг, выраженный в крайне бескультурном стиле. Идея отдачи Крыма промайданенной и фашиствующей Украине, невзирая на самоопределение крымчан, находит почти всеобщую поддержку в либеральной среде.

- «Не было никакого воссоединения. Была банальная оккупация чужой территории. Воссоединение - это добровольный акт, а в Крыму было насилие над Украиной. Зверское, лицемерное насилие над страной, которая пытается вырваться из лап русской цивилизации. Да и цивилизация ли это, тоже вопрос. По мне нет. Это просто территория, много веков диктующая своим соседям как надо жить» (цит. по: Михалков и Собчак ..., , 2014: Электронный ресурс).

Так Андрей Макаревич высказался о Крымском референдуме. Здесь тоже мы усматриваем типичный либеральный сепаратизм. Только высказывание музыканта было бы полным и, возможно, отчасти состоятельным, если бы он потрудился доказать, что вместо голосования крымчан была оккупация. Если российская цивилизация диктует нормы жизни всем соседям, то американские ястребы бомбят одни отдаленные от себя страны, в других (типа той же Украины) совершают выгодные для себя госперевороты, а третьи оккупируют методом экономического закабаления. Но Макаревича как истинного и последовательного либерала это не смущает.

- «Лично для меня самым оптимальным вариантом на месте этого гигантского кровавого монстра было бы 10 удельных княжеств, которые занимались бы внутренними разборками, которые бы там воевали друг с другом, а дальше, за поребрик, больше бы не лезли. Вот меня бы это устроило вполне. После этого я бы закончил свою оппозиционную военно-корреспондентскую деятельность и пошел бы писать детские книжки. Вот для меня это был бы 
лучший вариант» (Аркадий Бабченко; цит. по: «Апрельские тезисы» ... , 2018: Электронный ресурс).

Так либерал хочет «обустроить» Россию. И дело не в том, что эта фраза высказана отдельно взятым человеком. Главное - такая идея не является маргинальной в сообществе «креативного класса», готовом отдать на заклание не просто национальные богатства, а Россию в целом.

- «Россия должна платить за финансовую стабильность США» (Аркадий Дворкович; цит. по: Дворкович .., 2015: Электронный ресурс).

Хочется спросить, не ошибся ли автор этих слов гражданством, паспортом, местом жительства и работы. Такая позиция в совокупности с деятельностью, на ней основанной, представляются не намного худшим предательством национальных интересов, чем измена генерала во время войны. Фундаментальный порок современного проникнутого либерализмом государства видится в том, что люди, позволяющие себе подобные высказывания и действия, продолжают занимать высокие должности.

- «Что вы волнуетесь за этих людей? Ну, вымрет тридцать миллионов. Они не вписались в рынок. Не думайте об этом - новые вырастут».

В этих словах, которые цитируются в качестве сказанных Анатолием Чубайсом, мы видим прямой признак фашизма. Основа фашизма - сегрегация людей, разделение их на высших и низших, избранных и отверженных. Кстати, транснациональные капиталисты, в интересах которых работают российские либералы, давно уже выдумали фашистскую идею «золотого миллиарда» и планомерно идут к ее реализации. На это указывает новейшая история человечества. Только от классического фашизма идея «золотого миллиарда» отличается интернациональным характером. Но российские либералы, рядящиеся в одежды демократов, не позволяют себе критиковать сегрегационизм как идеи «золотого миллиарда», так и реальные действия глобальной корпоратократии, которые стоит квалифицировать как военную, экономическую, информационную и политическую агрессию. После нее «отреформированные» глобалистами страны терпят экономический и политический кризис, а сами «реформаторы» упрочивают свои позиции, и «золотой миллиард» укрепляется за счет других, отверженных. Российские либералы стали «реформирующими» Россию руками транснационалов.

Неважно, высказывал ли Чубайс фразу по 30 миллионов или она является выдумкой В. П. Полеванова (есть такое мнение, и Анатолий Борисович сам отрицает эти слова как сказанные им), факты говорят за себя:

1) транснационалы используют по-настоящему фашистские идеологию и стратегию для своего доминирования;

2) российские либералы стоят на их службе; 
3) младореформаторы отреформировали Россию так, что результаты их деятельности говорят о дикой ненависти и к России и к ее народу.

А. Б. Чубайс виновен в катастрофической для страны ваучерной приватизации, в дефолте 1998 г. (он тогда занимал пост министра финансов), позже он провел реформу электроэнергетики так, что тарифы пошли ввысь. Заодно расскажем историю, которую поведал М. Г. Делягин в передаче «Личные деньги» (20 декабря 2018 г.; см.: Здравоохранение РФ ... 2018: Электронный ресурс). ФСБ пресекло приватизацию Роснано весной 2018 г., назвав запланированное попыткой вывести из-под государственного контроля активов на 147 млрд руб. Чубайс перед этим получил от государства более 380 млрд рублей (более 130 млрд руб. прямого финансирования из бюджета и 252 млрд руб. государственных гарантий). Т. е. «эффективный менеджер» сократил активы, превратил 380 млрд в 147 млрд руб. Подобные этому факты говорят не просто о тотальном грабеже страны, учиненном либералами. Они указывает на то, что именно либерализм, в отличие от советского строя, расписался в неуважении к собственности. К тому же АО «Роснано» было учреждено для создания и развития передовых технологий, которых от этой организации мы не дождались. Следовательно, Чубайс свою задачу не выполнил, что должно повлечь в отношении его персоны последствия, связанные с ответственностью и обязательствами. Но их нет.

В ноябре 2019 г. разразился скандал после того, как профессор Высшей школы экономики (этого центра рыночных реформ) Гасан Гусейнов написал в соцсети сообщение о том, что русский язык является убогим и клоачным. Я отправил ему обличительное письмо, и завязалась непродолжительная переписка (Переписка ..., 2019: Электронный ресурс). Гусейнов пытался манипулировать, говорил, что его не поняли, что он имел в виду язык СМИ и политиков. Но в первоначальном сообщении фигурировал русский язык вообще, т. е. без отсылки к каким-либо социальным группам, его использующим. И Гусейнов не считает себя виновным ни в чем. Своей выходкой он не просто нанес оскорбление русскому народу, а спровоцировал негодование этнического характера, «столкновение цивилизаций»; так, стали появляться посты типа «с какой стати всякие нерусские будут нас убеждать в качестве нашего языка?». Такие посты являются вполне ожидаемыми и прогнозируемыми после подобных выходок, но их ни в коем случае нельзя назвать морально оправданными. Руководство ВШЭ и либералы в соцсетях принялись защищать Гусейнова. Короче, они снова встали на защиту русофобов, при этом зачастую отрицая всякое наличие русофобии как явления.

Можно дать более глубокие и развернутые комментарии к этим перлам. Можно и перлов перечислить намного больше. Но достаточно ограничиться приведенными примерами. 


\section{ОСОБАЯ КАСТА «СВОИХ»}

Весьма примечательно выглядит следующее несоответствие. В докладах американских структур типа RAND Corporation говорится, что Россию нужно ослаблять разными способами - в том числе посредством неолиберальных реформ. Российские либералы проводят эти же реформы и утверждают, что они приведут к развитию страны. Т. е. геополитическое и геоэкономическое оружие, стреляющее в Россию, они считают благом для нашей страны, хотя американские эксперты его называют именно оружием.

Как отметил О. В. Парилов, «либерализм, доведенный до крайности, это русоненавистничество как смысл жизни, презрение к России, русскому народу, имеющие метафизические основания, во всяком случае, рационально необъяснимые (вспомним недавно ушедшую в мир иной В. И. Новодворскую, ныне здравствующего К. Борового и др.)» (Парилов, 2016: 229). Однако сегодняшние либералы отрицают губительность реформ своих предшественников. Они по-прежнему выступают за приватизацию, за уход государства из экономики, за открытие страны транснациональному капиталу, что в результате вызывает чудовищное обнищание народа.

Особая каста - это так называемые либеральные правозащитники. Вооружившись концептом «права человека», они ловко им манипулируют, реализуя права только «отдельного человека». Они проявили поддержку тем, кто активно борется не с Кремлем, а именно с Россией. Либеральные правозащитники выступали на стороне убийцы русских людей Савченко и террориста Сенцова. Но они проявляют поразительный дар молчания даже при виде того, как власти «просвещенного» мира кого-либо сажают без суда и следствия. Когда в РФ службы правопорядка оказывают даже мягкое давление на акции протеста, либеральные защитники прав человека решительно изобличают тоталитарную власть. Но если на Западе происходит куда более жесткое вмешательство силовиков в проводимые политически активными группами антиправительственные мероприятия, либеральные правозащитники отводят взгляд. Они сохраняют безмолвие в деле Виктора Бута, которого в США по надуманному предлогу лишили свободы. Эти либерал-юристы не хотят ничего знать про бесправных узников американской тюрьмы Гуантанамо (где люди годами содержатся без предъявления обвинения), про подвергшихся издевательствам заключенных в Абу-Грейб, про многочисленных жертв секретных тюрем ЦРУ, выстроенных практически по всему миру. Это им просто неинтересно. Они предпочитают молчать, когда на Украине, в целом на Западе происходят случаи дискриминации русских людей. Они проявляют нехватку внимания к прибалтийским реалиям: ограничения в приеме на работу, лишение возможности для экономической и культурной активности, физическое насилие, диффамация в массмедиа, наступление на русский язык, лишение русских людей 
гражданских прав. Можно без преувеличения сказать, что они защищают права Запада давить на Россию. Если человек является сторонником либерализма, да еще и геем, он заслуживает большей поддержки, чем вполне нормальный патриот. Если этот гей - педофил, многих «либералов от права», подкованных на защиту меньшинств от большинства, данный факт не смущает.

Для большей иллюстративности расскажем следующую историю. В 2009 г. в США было введено юридическое понятие «неграждане, ведущие предпринимательскую деятельность в юрисдикции США» и потому обязанные платить Штатам налоги. Под «юрисдикцию США» может подпасть всякое общение с американцами, проводимые вне США операции без участия их граждан и компаний с использованием долларов. Нерезиденты США, получается, обязаны платить этой стране налоги только потому, что имеют какие-то связи с американцами и/или используют доллары. В качестве налогового преступления можно квалифицировать консультацию, оказанную не только американцу, но и вступившему с ним в отношения лицу, или тому, кто приобрел доллары США. С помощью такого нововведения можно повысить выплаты в бюджет Штатов, развязать себе руки в деле арестов иностранцев и поспособствовать дальнейшему расширению американского влияния в мире. Менее чем за год тюрьмы США наполнились несколькими десятками респектабельных иностранцев, которых вызвали в суды в качестве свидетелей и быстро переоформили в обвиняемых. Когда европейские банки в ответ стали отказываться даже открывать счета подданным США, данное правило перестало применяться. Однако оно вполне может возобновить свою функциональность, тем более Штаты итак по абсолютно безосновательным обвинениям арестовывают иностранных граждан (примеров тут можно привести много помимо истории с В. А. Бутом) (Делягин, 2019). В тот момент список угроз для граждан всех стран мира (кроме США) расширился; к описываемым теоретиками концепции общества риска угрозам добавилась еще одна — в одночасье стать обязанным платить налоги мировому гегемону на совершенно непонятных основаниях.

Для нас в данном контексте интересно то, что российские либеральные правозащитники не удостоили своим вниманием эту экспансионистскую инициативу и творимую на ее основе практику обвинений в отношении иностранных граждан. Зато они постоянно критикуют именно российские суды. Да, в деятельности нашей судебной системы - огромное количество нарушений. Достаточно вспомнить недавнее «Дело Сети», в рамках которого были незаслуженно обвинены на многолетние сроки несколько левых активистов. Но проблема в том, что либеральные сторонники прав и свобод отказываются быть последовательными. Не уставая раздувать пузырь проблем, связанных с 
российским правоприменением, они совершенно пренебрегают критикой даже еще более юридически бестактных и антидемократических правовых инициатив, принимаемых в «цивилизованном» мире. Как бы отреагировали выкормленные рыночной идеологией защитники прав, если бы в РФ приняли подобное постановление и решили юридически легитимной мерой привлекать к ответственности неграждан России, которые взаимодействуют с ее гражданами или используют рубли? Очевидно, поднялась бы волна возмущения.

На собственных митингах либералы активно пропагандируют свободу слова, клеймят власть, которая эти свободы ограничивает, но не пускают к микрофону социалистически и патриотически настроенных людей. Получается, они мало чем отличны от своих оппонентов. Похоже, свобода слова распространяется только на либералов.

Либералы защищают «своих» и нещадно бьют законом по «чужим». Так, после драки М. Л. Шевченко и Н. К. Сванидзе либерал-юристы подняли волну возмущения действиями Шевченко, хотя зачинщиком потасовки был Сванидзе; просто Шевченко «чужой», а Сванидзе «свой». «Своим» допустимо бить «чужих», но «чужие» таких привилегий лишены, они вообще не имеют права защищать свои права. Когда юридическое наказание распространяется на проворовавшихся «своих» деятелей искусства, либерал-юристы начинают кричать о произволе властей, несмотря на то, что факт хищения доказан. Если власти отказываются спонсировать фильмы и театральные постановки (обычно носящие аморальный и русофобский характер) «своей» для либералюристов творческой интеллигенции, инициируется волна возмущения; хотя сама теория либерализма гласит, что государство должно стоять в стороне от финансовой поддержки кого бы то ни было. Так либеральными правозащитниками реализуется концепт прав человека в одностороннем порядке. «Свой» априори прав, даже если виновен в преступлении, а «чужой» априори преступник или по крайней мере лицо, не заслуживающее защиты. Когда под гнет правоохранительных органов попадает за критику власти социалист, социал-демократ, убежденный марксист или обычный рабочий, представители «креативного класса», юристы, художники и журналисты не торопятся за него заступаться. Этим они тоже показывают, что демократичность либерализма сводится к защите исключительно либералов. Здесь мы наблюдаем серьезную этическую проблему; если человек является действительным правозащитником и сторонником демократии (каковыми себя выставляют либералы), его солидарность должна распространяться на всякого пострадавшего от произвола властей, несмотря на политические взгляды. Да и с темой прав человека у либералов серьезная проблема. Право на жилище, достойный заработок, безопасность существования, бесплатные и качественные образование и здраво- 
охранение, жизнь не просто игнорируются либеральными защитниками прав человека, а отвергаются.

Ранее как отечественные, так и западные либералы проявляли аналогичную односторонность, становясь вместо правозащитников полузащитниками. А. Тарасов приводит следующие примеры. Ими устраивались бурные пропагандистские кампании в защиту сторонников капитализма в Советском Союзе, когда тех преследовали; эти же либералы игнорировали, например, трагедию народа Абхазии, которого удушали голодом из-за блокады, установленной Шеварднадзе и Ельциным. Либералы выступали за свободу выезда из СССР, ссылаясь на ст. 13 Всеобщей декларации прав человека; они же принялись нарушать эту статью, ограничивая въезд в свои страны. Либералы критиковали СССР за использование принудительного труда заключенных, но в восьми штатах США законодательно в 1990-х гг. вводился принудительный труд находящихся в тюрьмах граждан. Либералы называли Берлинскую стену «позорном символом тоталитаризма», а потом американские элиты вознамерились возвести стену по всей границе США с Мексикой (Тарасов, 1999:Электронный ресурс).

\section{ЗАПАДНАЯ АНГАЖИРОВАННОСТЬ РОССИЙСКИХ ЛИБЕРАЛОВ}

Принятые Штатами и их приспешниками антироссийские санкции это санкции именно против России, а не ее правительства. Но если Вашингтон настроен гуманистически в отношении народа нашей страны и воинственно — против авторитарной коррумпированной власти, не позволяющей обществу развиваться, почему он вводит санкции, которые бьют не по власти, а по всему обществу? Либералы не ставят вопрос таким образом, поскольку продолжают в своей риторике нести веру в то, что американские чиновники стремятся привести свободу и процветание во весь мир. Они отказываются признавать недружественность направленных против России санкций, которая видна невооруженному глазу. Кстати, когда Россия ввела ответные санкции, западные лидеры, уверенные в безнаказанности своих действий, проявили непонимание. Ведь право вводить санкции имеют только они в одностороннем порядке, а когда кто-то инициирует санкции в отношении их стран, это квалифицируется как беспредел.

Запад (в очередной раз) продемонстрировал России свой истинный лик. Давно маски сброшены, уже не первый год очевидно, что те представители «цивилизованного» мира, которых на дипломатическом языке принято называть партнерами, являются крайне циничными и наглыми конкурентами. Но как занимающие высокие государственные должности, так оппозиционные представители либеральной мифологии по-прежнему предлагают глубже 
встраивать страну в существующий глобализационный порядок, т. е. отдавать ее в алчные руки корпоративного (и спекулятивного) международного бизнеса. Они всячески сторонятся альтернативного проекта по защите национальных интересов России, называя эти интересы национальным эгоизмом и чуть ли не нацизмом. Когда же западные страны планомерно отстаивают свои национальные интересы, российские либералы предпочитают на это смотреть спокойно.

Либерально мыслящие политики не спешат ограничивать приходящий в нашу страну спекулятивный капитал. Они отказываются на введенные против России санкции отвечать словом «нет» западным компаниям, которые захватили российский рынок. Даже когда Запад снова устроил против России настоящую травлю, когда направил против нас всю мощь своего идеологического, политического и экономического оружия (благо, не военного), когда расписался в поддержке откровенно русофобски настроенных украинских нацистов, российские либералы продолжают объяснять все происходящее с позиций априорной доброты Запада.

После убийства Б. Е. Немцова его идейные сподвижники назвали его именем мост и стали нести дежурство на месте убийства. Но они не оплакивает жертв американской геополитики - сербов, иракцев, афганцев, ливийцев и многих других. Этим либералам нет дела до убитых украинскими террористами мирных жителей Донбасса. Напротив, они полностью солидаризировались с нацистским правительством Украины, тем самым окончательно сняв с себя всякие маски. Когда-то Макс Хоркхаймер говорил, что не желающие критиковать капитализм должны молчать и по поводу фашизма. Аналогичным образом скажем: те, кто не желает критиковать украинский нацизм, должны молчать относительно прав человека. Либералам неинтересны судьбы тех десятков миллионов, которые просто не вписались в рынок и погрузились на социальное дно после реформ 1990-х гг. Для них смерть Немцова, внесшего немалый вклад в рыночное разграбление России, важнее всех других катастроф, которые большинство скорбящих по Борису Ефимовичу в качестве катастроф не признает.

Находящиеся у власти в РФ либералы сохраняют жизнь утвердившейся практике покупки государственных облигаций США, финансирующей экономики наших конкурентов. Именно здесь приходит на ум поговорка про глаза и божью росу. Кажется, что бы ни делали США и их союзники в отношении России, какие бы антироссийские проекты ни реализовывали, наши либералы все равно будут вещать о хорошем отношении Америки к России и принимать выгодные Западу политические и экономические решения. Вспомним утверждение Ф. Ницше: «Что требует самых основательных, самых упорных до- 
казательств, так это очевидность. Ибо слишком многим недостает глаз, чтобы видеть ее» (цит. по: Ницше ... , 1998: 38; см. также: Кара-Мурза, 2016: 55).

Либеральный догматизм не знает пределов. Он проявляет себя с особенным рвением и после того, как 90-е гг. показали крайнюю катастрофичность рыночных реформ для России, а мировая история продемонстрировала трагичные последствия либеральной политики в разных странах. Как сказал И. Лакатос, «слепая приверженность какой-либо теории не является интеллектуальным достоинством: скорее, это интеллектуальное преступление» (Лакатос, 2003: Электронный ресурс). Применительно к либерализму следует говорить далеко не только об интеллектуальном преступлении - ведь последствия либеральной политики затрагивают все общественное (экономическое, культурное, геополитическое) бытие в его многообразии.

Можно ли представить, что глупость всех этих деятелей не позволяет им понять реальные - совсем недружественные - цели Запада в отношении к России как таковой? Конечно, нет. Речь должна идти не о глупости, а о сознательном ведении борьбы на «той стороне» баррикад. На ум приходит известная фраза-вопрошание о глупости или измене. Один американец не от большого ума заявил: «То, что хорошо для “Дженерал моторс", хорошо для Америки». Его за эту фразу предали серьезному остракизму. Похоже, российские либералы думают аналогичным образом: то, что хорошо для «Дженерал моторс», хорошо для России.

Некоторые либералы открыто призывают Штаты усилить санкции против России, что равнозначно призыву нанести стране (именно стране, а не ее правительству) максимальный вред. Когда США устанавливают экономическую блокаду России, закрывают ее массмедиа, расширяют санкционные списки, либералы чувствуют прилив бодрости. Они, как бывший адвокат Рussy Riot M. 3. Фейгин, буквально просят американский истеблишмент усилить давление на Россию. Так, может, завтра они будут просить бомбить нашу страну. Кто-то скажет, что я сейчас сильно преувеличил зловредность либералов. Но где та черта, где тот рубикон вредоносности, который они никогда не перейдут? Она никем не обговорена.

Вопрос заключается в том, насколько справедливо применять к отдельным либералам и к либерализму в целом такую характеристику, как национальное предательство. Для большинства либералов не существует понятий типа «национальные интересы», следовательно, и предавать становится некого. Для них народ воспринимается как население, которое представляется неправильным, архаичным, дремучим. Нередко либералы с гордостью позиционируют свои действия по борьбе с Россией, выставляя их в качестве подвига. Вместе с тем они «включают» демагогию, при помощи которой оправдывают антироссийскую деятельность, называя ее настроенной не против 
России, а исключительно против господствующей власти, выставляя свои действия нужными и необходимыми именно для развития России. Здесь они в некотором роде берут пример с Н. Макиавелли, когда говорят вовсе не то, во что верят, не верят в то, что говорят, и если когда-то вещают правду, то окутывают ее ложью, которую трудно обнаружить. Только непонятно, как приватизация и последующий переход активов страны за рубеж, покупка Россией государственных облигаций США, отказ государства от социальной политики и прочие рекомендации поспособствуют развитию России. В общем, феномен воинствующего либерализма получается антипутинский по форме и антироссийский по содержанию.

Именно силы, разрушившие Россию в 1990-е гг., западная пропаганда считает прогрессивными. Когда же в РФ наблюдается слабая тенденция выдавливания либералов из стен государственных кабинетов, когда правительство осторожно пытается ограничить крупный бизнес (сформированный грабительской приватизацией) и управляющий им олигархат, Запад начинает вещать об откате назад, шовинизме, нарушении прав человека и принципа частной собственности. Это вполне закономерно - ведь нашим геополитическим конкурентам выгодна по-ельцински слабая Россия, которой правит либерализм.

Уже давно не является секретом то, что американцы вкладывают огромные деньги для поддержки «своей» оппозиции в интересующих их странах. Ряд российских либералов напрямую работают в интересах западных стран. Они получают от иностранных структур финансовую и иную помощь, держат там свои счета, перевозят туда свои семьи, устраивают детей учиться в западные учебные заведения. Они постоянно осуществляют контакты с американскими коллегами. Им дают возможность с помпой выступать в госструктурах США, они получают на Западе престижные премии и награды. Тот же А. А. Навальный обучался в Йельском университете. Б. Е. Немцов постоянно посещал политические круги США. Одна из лидеров так называемого правозащитного движения Л. М. Алексеева была похоронена в Вашингтоне. Риторика этих оппозиционеров носит абсолютно антироссийский характер. За риторикой оппозиционности режиму они скрывают свою оппозиционность России.

Широкий резонанс получил выложенный в Интернете видеоролик, где запечатлены Б. Е. Немцов, Е. С. Чирикова и другие активисты правого крыла, входящие в здание американского посольства к послу Майклу Макфолу. Когда к ним обратились журналисты с вопросом «Зачем вы сюда пришли?», оппозиционеры ничего вразумительного не ответили. Смущение и молчание, которые редко проявляют уверенные в себе красноречивые политики, указывают на сокрытие чего-то - в данном случае настоящей цели визита в американ- 
ское посольство. Уже позже либералы говорили, что, мол, поход в американское посольство был осуществлен для того, чтобы в России работали законы. Такое объяснение и многие последующие выглядят смешными и банальными. Непонятно, каким образом поход к американскому послу поспособствует работе российских законов. Почему-то американская оппозиция не идет в русское посольство в США для того, чтобы заработали американские законы.

Бывший премьер-министр М. М. Касьянов передавал в США списки журналистов и политиков, требуя ввести против них санкции (см.: Современный ..., 2015).И это при том, что очевидно отсутствие гуманистически-демократической направленности в американских санкциях и в их внешней политике в целом. Можем ли мы себе представить, чтобы в 1941 г. какой-нибудь советский гражданин открыто и без стеснения передавал какую-либо информацию Вермахту и просил ударить его посильнее по Советскому Союзу?

Когда был схвачен Джулиан Ассандж, либералы воспылали восторженными чувствами. Они рады тому, что рука «правосудия» дотянулась до человека, который выступал за свободу слова, открытость информации и изобличал преступления, совершенные мировым гегемоном. Здесь мы в очередной раз находим подтверждение тезису, что российские либералы заражены низкопоклонством перед американскими элитами - и неважно, в какой мере последние ведут борьбу с подлинной демократией.

\section{ЗАКЛЮЧЕНИЕ}

Проблема в том, что вести подрывную, вовсе не антипутинскую, а именно антироссийскую деятельность в РФ, как оказывается, весьма легко. Вместо ответственности она сопрягается с безнаказанностью. Крупных персон либеральных кругов не коснулось никакое наказание ни за подписание Беловежских соглашений, ни за разграбление страны в ельцинское время и позже. Более того, многие из виновных в политическом, геополитическом и экономическом подрыве России изнутри до сих пор занимают высокие государственные посты.

Эти люди - наемные работники, которые не бытийствуют либералами, а именно работают ими. Причина их приверженности либерализму - обычная корысть. Другие люди никем не ангажированы и просто в силу идейных соображений поддерживают либеральную идеологию, которая им представляется максимально передовой, современной и интеллигентной. Причина их либерализма - явная форма заблуждения.

Именно от этого заблуждения следует спасать общественное сознание нашей страны. 


\section{СПИСОК ЛИТЕРАТУРЫ}

«Апрельские тезисы»: развалить Россию на княжества и их стравить съезд несистемной оппозиции в Вильнюсе (2018) / М. Акинченко (корр.) [Электронный ресурс] // Первый канал. 12 апреля. URL: https://www.1tv.ru/ news/2018-04-12/343905-aprelskie tezisy razvalit rossiyu na knyazhestva i ih stravit_s ezd nesistemnoy_oppozitsii_v_vilnyuse [архивировано в WaybackMachine] (дата обращения: 21.05.2020).

Боровой - россиянам: На колени, твари, и просить прощения у нескольких поколений украинцев! (2014) / К. Н. Боровой, Т. Орел (корр.) [Электронный ресурс] // ГОРДОН. 3 августа. URL: https://gordonua.com/publications/ borovoy-rossiyanam-na-koleni-tvari-i-prosit-proshcheniya-u-neskolkih-pokoleniyukraincev-34602.html [архивировано в WaybackMachine] (дата обращения: 21.05.2020).

Быков, Д. Л. (2012) Программа Путина [Электронный ресурс] // Профиль. № 1 (749). 16 января. URL: http://www.profile.ru/items/?item=33972 [apхивировано в WaybackMachine] (дата обращения: 21.05.2020).

Грамши, А. (1959) Избр. произв.: в 3-х т. М. : Изд-во иностр. лит. Т. 3: Тюремные тетради / пер. с итал. В. С. Бондарчука [и др.]. 565 с.

Грамши, А. (1991) Тюремные тетради : в 3 ч. / пер. с итал. М. : Политиздат. Ч. 1. 560 с.

Данилевский, Н. Я. (1991) Россия и Европа. М. : Книга. 573, [1] с.

Дворкович «передал привет» Гайдару (2015) / В. Ваньков (корр.) [Электронный ресурс] // Свободная пресса. 19 июня. URL: https://svpressa.ru/ economy/article/125505/ [архивировано в WaybackMachine] (дата обращения: 21.05.2020).

Делягин, М. Г. (2016а) Новая Россия. Какое будущее нам предстоит построить. СПб. : Питер. 320 с.

Делягин, М. Г. (2016b) Россия в большой игре. На руинах потсдамского мира. М. : Книжный мир. 352 с.

Делягин, М. Г. (2019) Конец эпохи: осторожно, двери открываются! Изд. 12-е, перераб. и доп. М. : ИПРОГ ; Книжный мир. Т. 1: Общая теория глобализации. 832 с.

Здравоохранение РФ - это истребление людей, это просто бизнес (2018) / М. Г. Делягин [Электронный ресурс] // Delyagin TV — YouTube. 20 декабря. URL: https://youtu.be/vKAwchYGaG4 (дата обращения: 21.05.2020).

Зеленов, Л. А., Большаков, М. Г., Владимиров, А. А. (2018) Русофобия : монография. Н. Новгород : ВГУВТ ; ОАЧ. 144 с.

Ильин, А. Н. (2018а) Неолиберализм: опасные последствия // Свободная мысль. № 3 (1669). С. 13-26. 
Ильин, А. Н. (2018b) Русофобия / с предисл. Н. Старикова. СПб. : Питер. $320 \mathrm{c}$.

Ильин, А. Н. (2018c) «Снятие» либерализма как метапроблемы - залог формирования государства будущего // Государство будущего: актуальные проблемы социально-экономического и политико-правового развития: сб. ст. по матер. IV Междунар. науч.-практ. конф., посвященной 70-летнему юбилею УГНТУ / под общ. ред. проф. Э. С. Гареева. Уфа : Изд-во УГНТУ. 582 с. С. 207-210.

Ильин, А. Н. (2018d) Пенсионная реформа - это неолиберальное наступление на права трудящихся [Электронный ресурс] // Академия тринитаризма. 17 сентября. URL: http://www.trinitas.ru/rus/doc/0012/001f/00124553.htm [архивировано в WaybackMachine] (дата обращения: 21.05.2020).

Кара-Мурза, С. Г. (2016) Развилки современной глобализации // Проблемный анализ и государственно-управленческое проектирование. Т. 9. № 1 (45). С. 52-74.

Козин, Н. Г. (2006) Искушение либерализмом // Вопросы философии. № 9. С. 47-66.

Лакатос, И. (2003) Наука и псевдонаука (Выступление в радиопрограмме Открытого университета 30 июня 1973 г.) / пер. М. Каревой под ред. А. Щетникова [Электронный ресурс] // Здравый смысл. № 3. С. 17-20. URL: http://www.nsu.ru/classics/pythagoras/Lacatos.pdf [архивировано в WaybackMachine] (дата обращения: 21.05.2020).

Люблю евреев, потому что все русские - быдло! (2008) / К. А. Собчак, A. Никонов (корр.) [Электронный ресурс] // Peoples.RU. 17 мая. URL: https:// www.peoples.ru/tv/Sobchak/interview11.html [архивировано в WaybackMachine] (дата обращения: 21.05.2020).

Михалков и Собчак поссорились из-за Украины и культуры (2014) / O. Гончарук (корр.) [Электронный ресурс] // КП в Украине. 4 сентября. URL: https://kp.ua/culture/468675-mykhalkov-y-sobchak-possorylys-yz-za-ukrayny-ykultury [архивировано в WaybackMachine] (дата обращения: 21.05.2020).

Наумкина, К. (2018) «Обостряет отношения»: Пушков раскритиковал Чубайса за обвинения россиян в неблагодарности к бизнесменам [Электронный ресурс] // Nation News. 9 декабря. URL: https://nation-news.ru/418296obostryaet-otnosheniya-pushkov-raskritikoval-chubaisa-za-obvineniya-rossiyan-vneblagodarnosti-k-biznesmenam [архивировано в WaybackMachine] (дата обращения: 21.05.2020).

Ницше неизвестный и неожиданный (1998) / Ф. Ницше. Симферополь : Реноме. 528 c.

Особое мнение (2013) / Е. Альбац, А. Венедиктов, О. Бычкова [Электронный ресурс] // Эхо Москвы. 15 октября. URL: https://echo.msk.ru/programs/ 
personalno/1177008-echo/ [архивировано в WaybackMachine] (дата обращения: 21.05.2020).

Палкой по голове (2006) / А. С. Кончаловский, А. Мельман (корр.) [Электронный ресурс] // Московский комсомолец. 14 июля. URL: https:// www.mk.ru/editions/daily/article/2006/07/14/180153-palkoy-po-golove.html [apхивировано в WaybackMachine] (дата обращения: 21.05.2020).

Парилов, О. В. (2016) О русской национальной идее, национализме и русофобии // Русский универсум в условиях глобализации: сб. ст. участников Всерос. науч.-практ. конф. / науч. ред. Е. В. Валеева ; отв. ред. С. В. Напалков; Арзамасский филиал ННГУ; Фонд «Русский мир». Саров : Интерконтакт. 461 c. C. $229-236$.

Переписка с Г. Гусейновым - автором высказывания об убогом и клоачном русском языке (2019) / А. Н. Ильин, Г. Ч. Гусейнов [Электронный ресурс] // Сайт Алексея Ильина. 9 ноября. URL: http://ilinalexey.ru/2019/11/09/ perepiska-s-g-gusejnovym-avtorom-vyskazyvanija-ob-ubogom-i-kloachnom-russkom-jazyke/ [архивировано в WaybackMachine] (дата обращения: 21.05.2020).

По лезвию ножа: как звезды рискуют превратиться в экстремистов (2015) / Е. Чалова [Электронный ресурс] // Федеральное агентство новостей. 9 октября. URL: https://riafan.ru/432282-po-lezviyu-nozha-kak-zvezdyi-riskuyut-pr evratitsya-v-ekstremistov (дата обращения: 21.05.2020).

Подрабинек, А. П. (2009) Как антисоветчик антисоветчикам... [Электронный ресурс] // Ежедневный журнал. 21 сентября. URL: http://ej.ru/?a=note $\underline{\mathrm{id}=9467}$ [архивировано в WaybackMachine] (дата обращения: 21.05.2020).

Сбруев, В. (2013) Владимир Меньшов об истоках либеральной русофобии [Электронный ресурс] // Макспарк. 27 января. URL: https://maxpark.com/ community/13/content/1788761 [архивировано в WaybackMachine] (дата обращения: 21.05.2020).

Современный российский либерализм. Происхождение, сущность и историческое значение. Совместное заседание Интеллектуального клуба «Свободная мысль» и Изборского клуба / А. И. Агеев, В. А. Бубнов, М. Г. Делягин, С. А. Карпенко, А. А. Нагорный, А. И. Фурсов (2015) // Свободная мысль. № 5(1653). C. 45-68.

Тарасов, А. (1999) Долой продажную буржуазно-мещанскую культуру посредственностей! Да здравствует революционная культура тружеников и творцов! [Электронный ресурс] // Альтернативы. № 3. С. 120-161. URL: https://www.alternativy.ru/old/magazine/htm/99 3/iv.htm [архивировано в WaybackMachine] (дата обращения: 21.05.2020).

Фурсов, А. И. (2018) Водораздел. Необуржуазия, или Всадники капиталистического апокалипсиса [Электронный ресурс] // Завтра. 11 марта. URL: 
http://zavtra.ru/blogs/vodorazdel_neoburzhuaziya_ili_vsadniki_kapitalisticheskogo apokalipsisa [архивировано в WaybackMachine] (дата обращения: 21.05.2020).

Цитаты известных либералов (2011) [Электронный ресурс] // Politonline.ru. 7 января. URL: http://www.politonline.ru/provocation/7102.html [архивировано в WaybackMachine] (дата обращения: 21.05.2020).

Чирикова назвала российский народ «скотом» (2011) [Электронный реcypc] // Politonline.ru. 20 ноября. URL: http://www.politonline.ru/interpretation/ 12209499.html [архивировано в WaybackMachine] (дата обращения: 21.05. 2020).

Шафаревич, И. Р. (2005) Русофобия. М. : Эксмо ; Алгоритм. 348 с.

Юлия Латынина - Код доступа (2013)/ Ю. Л. Латынина [Электронный pecypc] // Эхо Москвы. 19 января. URL: https://echo.msk.ru/programs/code/992 938-echo/\#element-text [архивировано в WaybackMachine] (дата обращения: 21.05.2020).

Дата поступления: 23.05.2020 г.

\section{REFERENCES}

«Aprel'skie tezisy»: razvalit' Rossiiu na kniazhestva i ikh stravit' — s"ezd nesistemnoi oppozitsii v Vil'niuse [“April theses": Break up Russia into principalities and pit them against each other - congress of non-system opposition in Vilnius] (2018) / M. Akinchenko (corr.). Pervyi kanal, April 12. [online] Available at: https://www.1tv.ru/news/2018-04-12/343905-aprelskie tezisy razvalit_rossiyu na knyazhestva_i ih_stravit_s_ezd nesistemnoy_oppozitsii_v_vilnyuse [archived in WaybackMachine] (accessed 21.05.2020).

Borovoi - rossiianam: Na koleni, tvari, i prosit' proshcheniia u neskol'kikh pokolenii ukraintsev! [Borovoy - To the Russians: On your knees, bastards, and ask for forgiveness from several generations of the Ukrainians!] (2014) / K. N. Borovoi and T. Orel (corr.). GORDON, August 3. [online] Available at: https://gordonua.com/publications/borovoy-rossiyanam-na-koleni-tvari-i-prosit-proshcheniya -u-neskolkih-pokoleniy-ukraincev-34602.html [archived in WaybackMachine] (accessed 21.05.2020). (In Russ.).

Bykov, D. L. (2012) Programma Putina [Putin's Programme]. Profil', no. 1 (749), January 16. [online] Available at: http://www.profile.ru/items/?item=33972 [archived in WaybackMachine] (accessed 21.05.2020).

Gramsci, A. (1959) Izbrannye proizvedeniia [Selected works]: in 3 bks. Moscow: The Foreign Languages Publishing House. Vol. 3: Tiuremnye tetradi [Prison notebooks]/ transl. from Italian by V. S. Bondarchuk [et al.]. 565 p. (In Russ.).

Gramsci, A. (1991) Tiuremnye tetradi [Prison notebooks] : in 3 pts. / transl. from Italian. Moscow : Politizdat Publ. Pt. 1.560 p. (In Russ.). 
Danilevsky, N. Ya. (1991) Rossiia i Evropa [Russia and Europe]. Moscow : Kniga Publ. 573, [1] p. (In Russ.).

Dvorkovich «peredal privet» Gaidaru [Dvorkovich "sent greetings" to Gaidar] (2015) / V. Vankov (corr.). Svobodnaia pressa, June 19. [online] Available at: https://svpressa.ru/economy/article/125505/ [archived in WaybackMachine] (accessed 21.05.2020). (In Russ.).

Delyagin, M. G. (2016a) Novaia Rossiia. Kakoe budushchee nam predstoit postroit' [New Russia. What a future we will have to build]. St. Petersburg : Piter Publ. 320 p. (In Russ.).

Delyagin, M. G. (2016b) Rossiia v bol'shoi igre. Na ruinakh potsdamskogo mira [Russia is in the big game. On the ruins of the Potsdam world]. Moscow : Knizhnyi mir Publ. 352 p. (In Russ.).

Delyagin, M. G. (2019) Konets epokhi: ostorozhno, dveri otkryvaiutsia! [The end of the age: Watch out, the doors are opening!]. 12th edn., revised and supplemented. Moscow : IPROG Publ. ; Knizhnyi mir Publ. Vol. 1: Obshchaia teoriia globalizatsii [General theory of globalization]. 832 p. (In Russ.).

Zdravookhranenie RF - eto istreblenie liudei, eto prosto biznes [Healthcare of the Russian Federation is extermination of people, it's just a business] (2018) / M. G. Delyagin. Delyagin TV - YouTube, December 20. [online] Available at: https://youtu.be/vKAwchYGaG4 (accessed 21.05.2020).

Zelenov, L. A., Bolshakov, M. G. and Vladimirov, A. A. (2018) Rusofobiia : Russophobia]: A monograph. Nizhny Novgorod : Volga State University of Water Transport Publ. ; OACh Publ. 144 p. (In Russ.).

Ilyin, A. N. (2018a) Neoliberalizm: opasnye posledstviia [Neoliberalism: Dangerous consequences]. Svobodnaia mysl', no. 3 (1669), pp. 13-26. (In Russ.).

Ilyin, A. N. (2018b) Rusofobiia [Russophobia] / with foreword by N. Starikov. St. Petersburg : Piter Publ. 320 p. (In Russ.).

Ilyin, A. N. (2018c) «Sniatie» liberalizma kak metaproblemy — zalog formirovaniia gosudarstva budushchego ["Dismissal" of liberalism as a metaproblem The key to the formation of the state of the future]. In: Gosudarstvo budushchego: aktual'nye problemy sotsial'no-ekonomicheskogo $i$ politiko-pravovogo razvitiia [The state of the future: Actual problems of socio-economic, political and legal development] : A collection of papers presented at the4thInternational research-topractice conference dedicated to 70th anniversary of USPTU / ed. by professor E. S. Gareev. Ufa : Ufa State Petroleum Technological University Publ. 582 p. Pp. $207-$ 210. (In Russ.).

Ilyin, A. N. (2018d) Pensionnaia reforma - eto neoliberal'noe nastuplenie na prava trudiashchikhsia [Pension reform - A neoliberal attack on the rights of workers]. Akademiia trinitarizma [Academy of Trinitarianism], September 17. [online] 
Available at: http://www.trinitas.ru/rus/doc/0012/001f/00124553.htm [archived in WaybackMachine] (accessed 21.05.2020). (In Russ.).

Kara-Murza, S. G. (2016) Razvilki sovremennoi globalizatsii [The bifurcations of modern globalization]. Problemnyi analiz i gosudarstvenno-upravlencheskoe proektirovanie, vol. 9, no. 1 (45), pp. 52-74. (In Russ.).

Kozin, N. G. (2006) Iskushenie liberalizmom [Temptation by liberalism]. Voprosy filosofii, no. 9, pp. 47-66. (In Russ.).

Lakatos, I. (2003) Nauka i psevdonauka (Vystuplenie v radioprogramme Otkrytogo universiteta 30 iiunia 1973 g.) [Science and pseudoscience (A radio talk programme of The Open University on June 30, 1973)] / transl. by M. Kareva, ed. by A. Shchetnikov. Zdravyi smysl, no. 3, pp. 17-20. [online] Available at: http:// www.nsu.ru/classics/pythagoras/Lacatos.pdf [archived in WaybackMachine] (accessed 21.05.2020). (In Russ.).

Liubliu evreev, potomu chto vse russkie - bydlo! [I love the Jews, because all the Russians are simpletons] (2008) / K. A. Sobchak and A. Nikonov (corr.). Peoples.RU, May 17. [online] Available at: https://www.peoples.ru/tv/Sobchak/interview11.html [archived in WaybackMachine] (accessed 21.05.2020). (In Russ.).

Mikhalkov i Sobchak possorilis' iz-za Ukrainy i kul'tury [Mikhalkov and Sobchak quarreled because of Ukraine and culture] (2014) / O. Goncharuk (corr.). KP v Ukraine, September 4. [online] Available at: https://kp.ua/culture/468675-mykhalkov-y-sobchak-possorylys-yz-za-ukrayny-y-kultury [archived in WaybackMachine] (accessed 21.05.2020). (In Russ.).

Naumkina, K. (2018) «Obostriaet otnosheniia»: Pushkov raskritikoval Chubaisa za obvineniia rossiian v neblagodarnosti k biznesmenam ["Aggravates relations": Pushkov criticized Chubais for accusing Russians of ingratitude to businessmen]. Nation News, December 9. [online] Available at: https://nation-news.ru/41829 6-obostryaet-otnosheniya-pushkov-raskritikoval-chubaisa-za-obvineniya-rossiyanv-neblagodarnosti-k-biznesmenam [archived in WaybackMachine] (accessed 21.05. 2020). (In Russ.).

Nitsshe neizvestnyi i neozhidannyi [The unknown and unexpected Nietzsche] (1998) / F. Nietzsche. Simferopol : Renome Publ. 528 p.

Osoboe mnenie [Differing view] (2013) / E. Albats, A. Venediktov and O. Bychkova. Ekho Moskvy, October 15. [online] Available at: https://echo.msk.ru/programs/personalno/1177008-echo/ [archived in WaybackMachine] (accessed 21.05. 2020). (In Russ.).

Palkoi po golove [With a stick on the head] (2006) / A. S. Konchalovsky and A. Melman (corr.). Moskovskii komsomolets, July 14. [online] Available at: https: //www.mk.ru/editions/daily/article/2006/07/14/180153-palkoy-po-golove.html [archived in WaybackMachine] (accessed 21.05.2020). (In Russ.). 
Parilov, O. V. (2016) O russkoi natsional'noi idee, natsionalizme i rusofobii [On the Russian national idea, nationalism and Russophobia]. In: Russkii universum $v$ usloviiakh globalizatsii [The Russian universum in the context of globalization] : A collection of papers presented at the all-Russian research-to-practice conference / ed. by E. V. Valeev and S. V. Napalkov ; Arzamas branch of State University of Nizhni Novgorod ; "Russkiy mir" Foundation. Sarov : Interkontakt Publ. 461 p. Pp. 229-236. (In Russ.).

Perepiska s G. Guseinovym - avtorom vyskazyvaniia ob ubogom i kloachnom russkom iazyke [Correspondence with G. Guseinov - the author of the statement about the barren and crap Russian language] (2019) / A. N. Ilyin and G. Ch. Guseinov. Sait Alekseia Il'ina [Alexey Ilyin's Website], November 9. [online] Available at: http://ilinalexey.ru/2019/11/09/perepiska-s-g-gusejnovym-avtoromvyskazyvanija-ob-ubogom-i-kloachnom-russkom-jazyke/ [archived in Wayback Machine] (accessed 21.05.2020). (In Russ.).

Po lezviiu nozha: kak zvezdy riskuiut prevratit'sia v ekstremistov [On the edge of the knife: How stars risk to become extremists] (2015) / E. Chalova. Federal'noe agentstvo novostei, October 9. [online] Available at: https://riafan.ru/432282-polezviyu-nozha-kak-zvezdyi-riskuyut-prevratitsya-v-ekstremistov (accessed 21.05. 2020). (In Russ.).

Podrabinek, A. P. (2009) Kak antisovetchik antisovetchikam... [As an antiSoviet to anti-Soviets...]. Ezhednevnyi zhurnal, September 21. [online] Available at: http://ej.ru/? $\mathrm{a}=$ note\&id=9467 [archived in WaybackMachine] (accessed 21.05.2020). (In Russ.).

Sbruev, V. (2013) Vladimir Men'shov ob istokakh liberal'noi rusofobii [Vladimir Menshov on the origins of liberal Russophobia]. Maxpark, January 27. [online] Available at: https://maxpark.com/community/13/content/1788761 [archived in WaybackMachine] (accessed 21.05.2020). (In Russ.).

Sovremennyi rossiiskii liberalizm. Proiskhozhdenie, sushchnost' $i$ istoricheskoe znachenie. Sovmestnoe zasedanie Intellektual'nogo kluba «Svobodnaia mysl'» i Izborskogo kluba [Contemporary Russian liberalism. Origin, essence and historical significance. Joint meeting of the Intellectual Club "Free Thought" and the Izborsk Club] / A. I. Ageev, V. A. Bubnov, M. G. Deliagin, S. A. Karpenko, A. A. Nagornyi and A. I. Fursov (2015) Svobodnaia mysl', no. 5 (1653), pp. 45-68. (In Russ.).

Tarasov, A. (1999) Doloi prodazhnuiu burzhuazno-meshchanskuiu kul'turu posredstvennostei! Da zdravstvuet revoliutsionnaia kul'tura truzhenikov i tvortsov! [Down with the corrupt bourgeois and philistine culture of mediocre persons! Long live the revolutionary culture of workers and creators!]. Al'ternativy, no. 3, pp. 120161. [online] Available at: https://www.alternativy.ru/old/magazine/htm/99 3/iv. $\underline{\mathrm{htm}}$ [archived in WaybackMachine] (accessed 21.05.2020). (In Russ.). 
Fursov, A. I. (2018) Vodorazdel. Neoburzhuaziia, ili Vsadniki kapitalisticheskogo apokalipsisa [Watershed. Neo-bourgeoisie, or Horsemen of the capitalist apocalypse]. Zavtra, March 11. [online] Available at: http://zavtra.ru/blogs/vodorazdel_neoburzhuaziya_ili_vsadniki_kapitalisticheskogo_apokalipsisa [archived in WaybackMachine] (accessed 21.05.2020). (In Russ.).

Tsitaty izvestnykh liberalov [Quotes of famous liberals]. (2011) Politonline.ru, January 7. [online] Available at: http://www.politonline.ru/provocation/7102.html [archived in WaybackMachine] (accessed 21.05.2020). (In Russ.).

Chirikova nazvala rossiiskii narod «skotom» [Chirikova called the Russian people "cattle"] (2011) Politonline.ru, November 20. [online] Available at: http://www.politonline.ru/interpretation/12209499.html [archived in WaybackMachine] (accessed 21.05.2020). (In Russ.).

Shafarevich, I. R. (2005) Rusofobiia [Russophobia]. Moscow : Eksmo Publ. ; Algoritm Publ. 348 p. (In Russ.).

Yulia Latynina - Kod dostupa [Yuliia Latynina - Access code] (2013) / Yu. L. Latynina. Ekho Moskvy, January 19. [online] Available at: https:// echo.msk.ru/programs/code/992938-echo/\#element-text [archived in WaybackMachine] (accessed 21.05.2020). (In Russ.).

Submission date: 23.05.2020.

Ильин Алексей Николаевич - кандидат философских наук, доцент кафедры практической психологии Омского государственного педагогического университета. Адрес: 644043, Россия, г. Омск, ул. Партизанская 4а, ауд. 117. Эл. адрес: $\underline{\text { ilin1983@yandex.ru }}$

Ilyin Alexey Nikolaevich, Candidate of Philosophy, Associate Professor, Department of Practical Psychology, Omsk State Pedagogical University. Postal address: Aud. 117, 4a Partizanskaya St., 644043 Omsk, Russian Federation. E-mail: ilin1983@yandex.ru

\section{Сайт автора: http://ilinalexey.ru}

\section{Для изитирования:}

Ильин А. Н. Либерализм с русофобской спецификой [Электронный ресурс] // Горизонты гуманитарного знания. 2020. № 4. С. 52-88. URL: https://journals.mosgu.ru/ggz/article/view/1307 (дата обращения: дд.мм.гггг). DOI: $10.17805 /$ ggz.2020.4.4 